\title{
A Study of the Factors Determining Motivational Level of Employees Working in Public Sector of Bahawalpur (Punjab, Pakistan)
}

\author{
Atif Rafique \\ Department of Management Sciences, The Islamia University of Bahawalpur (Pakistan) \\ E-mail: atifrafique1671@gmail.com, Mob: +923076638867 \\ Muhammad Sadam Bin Tayyab \\ Department of Management Sciences, The Islamia University of Bahawalpur (Pakistan) \\ E-mail: m.sadamt@yahoo.com, Mob: +923146251621
}

Muhammad Kamran

Department of Management Sciences, The Islamia University of Bahawalpur (Pakistan)

E-mail: m.sadamt@yahoo.com, Mob: +923321650524

Nawab M. Ahmed

Department of Management Sciences, The Islamia University of Bahawalpur (Pakistan)

E-mail: nawabahmad909@ymail.com, Mob: +923018783711

Doi:10.5296/ ijhrs.v4i3.5872 URL: http://dx.doi.org/10.5296/ ijhrs.v4i3.5872

\begin{abstract}
This study empirically examines the relationship between rewards, job satisfaction, Perceived training effectiveness, knowledge transfer and organizational commitment and employee's motivation in the Public sector of Bahawalpur (Punjab, Pakistan).Our sample was public sector data was collected by using self-designed questionnaires. The sample size was 170 so 170 questionnaires were distributed and only 149 received. Analysis was done with the help of correlation coefficient and multiple regression analysis. Between (0.01 to 0.05) level of significance was checked. The result concludes that there is a significant positive relationship between intrinsic rewards and the employee's motivation and also there is significant positive relationship between extrinsic reward and employee's motivation. Job Satisfaction also has
\end{abstract}


significant positive relationship with employee's motivation. But on the other hand PTE (Perceived Training Effectiveness) have insignificant and negative relationship with Employee's motivation. Employee's motivation has significant positive relationship with knowledge transfer and also with Organizational Commitment.

Keywords: Employee motivation, Intrinsic Rewards, Extrinsic Reward, Job Satisfaction, Perceived Training Effectiveness, Knowledge Transfer, Organization Commitment, Public Sector Correlation, Regression, Punjab province, Pakistan

\section{Introduction}

Now a day's companies are facing many challenges in competitive environment and the one problem is to get efficient employees and to make them loyal is very challenging. Today the most important asset for any organization is human. Employee motivation is very important for the efficiency of human resource. Better reward system by management can increase the employee's performance. Organizations wants motivated workforce. Organizational survival is only because of motivated employees. To the effectiveness managers must know the motivational factors. Motivating employees is most difficult problem for manager in functions. It is important to identify that which factor is the most important for employee motivation (Bowen \& Radhakrishna, 1991). For example, research suggests that only money is not the perfect measuring tool for employee motivation (Kovach, 1987). For older employees interesting work can be the good motivator. The Working condition, the relationship between employer and employee, Opportunities for their career development, security for their job and over all organization appraising strategy are the following factors which affect employee's performance. Motivation is most important factor from all other factors to affect the employee performance. Combination of many techniques which compel our behavior to get some target is motivation (Baron, 1983). The relationship of intrinsic rewards (working environment, authority and recognition) extrinsic rewards (pay, promotion and bonuses), job satisfaction and perceived training effectiveness on motivation and more motivation's impact on organizational commitment and knowledge transfer.

There are two major categories of rewards Extrinsic and Intrinsic, extrinsic rewards also known as tangible rewards like salary/pay, incentives, bonuses, promotions, job security, etc. Intrinsic rewards can also be called intangible rewards or psychological rewards like appreciation, education, working environment title, authority, Attaining new targets, good behavior from boss and moving from one job to another after completing certain targets. Intrinsic rewards are better motivator after increasing salary to certain level Frey (1997) satisfaction on performing well and feeling wealthy are intrinsic rewards which are necessary for staff motivation.

Job satisfaction is a sense of feeling good because of rewarding; good behavior for job. Employee sincerity with work tells how much he is satisfied from job. Person's job satisfaction level can be affect by many factors. Few of these factors include certain level of pay and advantages, fair promotion system, good working facilities, hierarchy relationship, 
the job itself (the several targets includes, challenge generate by job and easily understandable job description). People feel sense of happiness when they are happy. Job satisfaction is different from motivation but has little linked.

The process of enhancing skills and knowledge is basically training. The purpose of training is getting new skills, problem solution ability and practical knowledge etc. present and future performance of employees can be increase by training. Motivation and commitment of employees can be affecting by direct and indirect training programs from organization (Meyer and Allen, 1991). Organizational commitment is defined, in the words of Pool and Pool (2007, p. 353) as “. . . the relative strength of an individual's identification and involvement in a particular organization". Training is done to prepare worker for job. Few organizations invest long term for the better skills of the worker to handle the present and future situations. This type of training makes employees more motivated and committed who are interested in career development. Individual characteristics also affect them toward motivation

Better performance and contribution towards work only because of motivated and committed employee (Brown, 2003:31).Individual's behavior for organization is the organizational commitment including (a) good perception and receiving of organization targets (b) a thirst to get membership in organization (c) wish to utilize all skills for organization (Mowday et al., 1982).For efficient management and team work in the organization knowledge transfer is necessary. For the generation of tangible rewards results like good life and also for non-tangible rewards results like sincerity to the organization that enable to see the career development in good working conditions and the moral values managers need to transfer knowledge. To increase the efficiency of organization managers need to encourage their employees.

\section{Literature Review}

\section{Motivation}

Ability to convert the attitude is motivation. Motivation is a determination that keeps someone in certain direction to achieve specific target. Combination of many techniques which compel our behavior to get some target is motivation (Baron, 1983). According to Maslow's Hierarchy of Needs model (Maslow, 1968); humans are motivated to fulfill five levels of needs: basic or physiological needs, safety needs, social needs, self-esteem needs and self-actualization needs. Therefore, people work hard to fulfill five needs. For example, people work to earn income to be able to have basic necessities such as food and have a place to stay. People work to have a sense of security, knowing that at the end of each month they will receive their salary that will enable them to live as securely as before. Some people may enjoy working because it provides them a social environment where they could network and deal with other people. In so doing, their social needs are fulfilled. People's esteem needs may be fulfilled when they receive respect and recognition for their work; and for some very lucky people, their self-actualization needs may be met by them doing work that they really enjoy and excel at.Employee's persistence, productivity and performance are influence by motivation (Grant 2008; Younas et al., 2013). Motivated employees are more loyal with their 
work and organization as compare to less motivate.(e.g. Ryan and Deci, 2000; Thomas, 2002, as cited in Grant, 2008), whichshows motivated employees will be more responsible development opportunities offered. Motivated employees show more commitment with the jobs.(e.g. Guay et al., 2000; Vansteenkiste et al., 2007; Rizwan et al., 2013); They do more struggle to achieve the organization goals as compare to low motivated employees.

\section{Intrinsic Reward}

Sometimes organizations more focus on extrinsic rewards but intrinsic rewards also very important in employee motivation. Appreciation and recognition are intrinsic rewards which motivate employees and improve the performance. Andrew (2004) employee's commitment depends on the rewards and recognition. Lawler (2003) Behavior with the human resources measures the prosperity and survival of the organization. Satisfaction after completing task, gratitude from boss, empowerment are the non-tangible rewards. Ajila and Abiola (2004).Intrinsic non-monetary rewards refer to rewards that are inherent to the nature of the job. Intrinsic non-monetary refers to pleasure able emotional state that individual receive against his work (Porter \& Lawler, 1968). They can thus be equated to what Kallerberg (1977) termed intrinsic job satisfaction.So the relationship of intrinsic job satisfaction and intrinsic non-monetary rewards are used interchangeably in this study. There are many consciences of Intrinsic job satisfaction which are motivation, emotional promise, retaining and efficiency. Kallerberg, 1977; Selden \& Brewer, 2000). Frey (1997) argues that intrinsic factors are better motivators when salary go beyond survival level, and for good performance staff need intrinsic rewards.

All around the world it is clear if you provide good working environment to your employees then they will automatically motivated toward their work and perform with their full potential. And if we provide them authority of decision making then they will motivated toward their work. Employees will motivate if we give them appraisal against their efforts. So we can argue that there is a relationship between intrinsic reward and employee's motivation.

H1: Intrinsic Reward has positive relationship with Employees Motivation.

\section{Extrinsic Reward}

Extrinsic rewards are salary, bonuses, safety, recognition, marginal benefits like transport. (Chen et al., 1999; Malhotra et al., 2007; Mottaz, 1985; Weatherly, 2002).Extrinsic non-monetary rewards are external social rewards like good relationship with member, management sport and appraise(Katz \& Van Maanen, 1977; Malhotra et al., 2007; Mottaz, 1985). Actual this study will emphasis on employees' opinions of administrative support. This study delivered practical prove that motivation and strong commitment attain by giving the control (Eisenberger, Stinglhamber, Vandenberghe, Sucharski \& Rhoades, 2002; Randall \& O'Driscoll, 1997; Williams, Brower, Ford, Williams \& Carraher, 2008).ENMRs are understood in line with Gagnon and Michael's (2004) definition the degree of employee's 
feeling about management help (p. 173). Extrinsic non-monetary rewards also play the important role in achieving organizational goals with efficiency (Amabile, Schatzel, Moneta $\&$ Kramer, 2004).Now a days every Organizations wishes to create equilibrium among the employee's commitment and performance of the organization.

Salary, promotion and bonuses are major components that motivate employees of any organization. If organization provide salary against his employee's efforts and promotion against his hard work and bonus for his extra time which he have given to the organization will motivate that employee.

H2: Extrinsic Reward has positive relationship with Employees Motivation.

\section{Job Satisfaction}

Job satisfaction means how the desired things are provided to employees that results their satisfaction the point of happiness during job due to receiving their planned benefits is the exact definition of job satisfaction. Low level of Job satisfaction lead to high turnover of employees and decrease employee's loyalty toward the organization (Moser, 1997).Turnover rate of dissatisfied employees are always high as compare to satisfied employees (Rusbult et al, 1988). Thus job satisfaction plays a major role in employee's commitment with the organization.

It is observed in any organization that satisfied employees happily put their maximum efforts to achieve organizational goals

H3: Job Satisfaction has positive relationship with Employees Motivation.

\section{Perceived Training Effectiveness}

Due to at a stretch enhancement in technology and introducing new techniques there is a problem for both employees and management and they can easily observe their demand in future. Studies show the emergence of two trends, increasingly troubling corporate management, the increasing age of the workforce and the fast-paced evolution of new technologies (Tai, 2006).According to Tai, researchers suggest to be competitive every organization should increase their training budgets, and hold skillful labor. Training is defined in this study "is planned to provide clear direction to perform their duties to achieve organizational goals .Training is basically used to enhance employee skills to perform their jobs and employees can easily achieve organizational decided goals. Training offered to employees, may help the employees how to perform easily their job well and reduced their tension about job performance who have less knowledge about their job (Chen et al., 2004 Employees will be demotivated due to having unaware of their duties and this thing will 
create lack of interest in employees and as a result turnover of the employees increases. Employees will be motivated if they have good training about their work. If they know about their work then they will try to give their full potential work. So we can say effective training leads toward employee's motivation.

H4: Perceived Training effectiveness have positive impact on employees Motivation.

\section{Knowledge transfer}

Knowledge transfer is the basic tool creates co-ordination between the employees of the organization so it is essential to well-organized management. Thus, supervisors are keenly enthusiastic to produce knowledge transfer to increase their extrinsic motivation such as their personal and professional life and also generate intrinsic motivation such as organizational commitment of the employees means knowledge is beneficial for both employees as well as to the organizations for achieving its goals According, to managers of any organization employees should create an environment of co-ordination and as a result those employees whose are not sharing their knowledge and should efficiently and effectively participate in achieving organizational goals .(Ryan) argues that without empowerment only recognition is not enough for motivation, so employees need not only practice apparent capability (or self-efficacy), they need also practice their actions to be self-determined if motivation is to be preserved. Employees are also motivated by transfer of knowledge and motivated employees are committed to the organization and committed employees put their maximum efforts to attain organizational goals In the same way, knowledge transfer create motivation to face challenges during work, because increase of tasks rises the need of knowledge sharing. Intrinsic rewards like Strong commitment among employee's increases decision making abilities (Walsh, 1995). Even though these organizational benefits may deliver temporary rewards for knowledge and abilities sharing, they are not an main force in establishing employees' knowledge-sharing behaviors (Lin, 2007).

H5: There is a relationship between Employees Motivation and Knowledge Transfer.

\section{Organizational Commitment}

Organizational commitment is more important for organizational behavior research. Organization commitment is basically strong beliefs of employees on organization and putting value able efforts to achieve organizational goals and want to maintain its members of the company (Mowday et al 1982). (Porter et al.1974).High level of satisfaction increase commitment of employee's with the organization and they want to achieve organizational goals with the core of their hearts (Luthans, McCaul, Dodd, 1985). Meyer \& Allen (1991 
categorize the organizational commitment into three major aspects: (1) Affective Commitment: refers to the employee's best feeling and empathy, and link with the organization. Highly affective committed employees continue their job with the organization.

(2) Continuance Commitment refers to an knowledge of the costs related with exit the organization. Employees whose primary link to the organization is based on continuance commitment remain because they need to do so. (3)Normative Commitment refers to the feeling of duty to carry on employment. High levels of normative committed employee's feel that they must to persist with the organization. Employee motivation may positively correlate with organizational commitment. High affective committed employee's would motivated to higher levels of performance than employees who stated continuance or normative commitment (Brown, 2003:31). Thus, commitment alone is one of the key concepts of employee behavior.

In this study we observed the link between employee's motivation and organizational commitment. A person will be committed with his organization if he has motivation toward his work.

H6: There is a relationship between Employees Motivation and Organizational Commitment.

\section{Research Methodology}

The current research is descriptive in its nature. Descriptive research can be explained as describing something, some phenomenon or any particular situation. Descriptive researches are those researches that describe the existing situation instead of interpreting and making judgments (Creswell, 1994). The main objective of the descriptive research is verification of the developed hypothesis that reflects the current situation. This type of research provides information about the current scenario and focus on past or present for example quality of life in a community or customer attitudes towards any marketing activities (Kumar, 2005).

\subsection{Sample Data}

In order to collect the data for understanding the situation about the employee's motivation in public Sector of Bahawalpur, a sample of 149 respondents was asked to participate in a self-administered questionnaire. The population for the current research is employees of public sector in Bahawalpur. The current study utilizes a no probability sampling technique that is convenience sampling. Convenience sampling is a sampling technique that obtains and collects the relevant information from the sample or the unit of the study that are conveniently available (Zikmund, 1997). Convenience sampling is normally used for collecting a large number of completed surveys speedily and with economy (Lym et al, 2010).

It is ensured that the sample members possess two main qualifications to participate in the self-administered survey. First, the sample members should have enough knowledge about 
employee motivation; secondly, they have a regular experience about employee's motivation, it definitely influences the attitude and behavior of the respondent.

\subsection{Instruments and Measures}

The survey instrument of the current study address two major purposes: First is to analyze the relationship of different variables in Employees motivation. Second, to collect information about the different characteristics of the respondents that can be used to understand the variations in different dimensions. The survey instrument contains two sections. Section 1 includes different personae and demographic variables. This section will obtain the respondent's information about gender, age, income and education.

Section 2 includes the latent variables that are important in the current study. These variables includes Extrinsic Rewards, Intrinsic Rewards, Job satisfaction and Perceived Training effectiveness are latent variables for employees motivation and more is that employees motivation is also latent variable for organizational commitment and knowledge transfer. This section of study is developed based on the past literature and already used questionnaires.

The scales of the study were adopted from the previous literature and published studies. The first variable of the study was employee's motivation having five items. The next variable is extrinsic rewards having seven items. The next variable is Intrinsic reward's having six items. The next variable job satisfaction have four items. Perceived training effectiveness have three items to judge its impact on employee's motivation. Knowledge transfer has three item and Organizational commitment have four items.

\subsection{Procedure}

The questionnaire was distributed among 149 respondents in Bahawalpur City of Pakistan. These respondents are selected based on the criteria above mentioned. Before giving the questionnaire, the purpose of the study and questions were explained to the respondents so they can easily fill the questionnaire with relevant responses. A total of 149 questionnaires selected. After collecting, the completed questionnaires were coded and entered into SPSS sheet for further analysis.

\subsection{Reliability Analysis}

\begin{tabular}{|l|l|l|}
\hline Variables & Items & Crounbach Alpha \\
\hline Employee's Motivation & 5 & 0.788 \\
\hline Extrinsic Reward & 7 & 0.769 \\
\hline Intrinsic Reward & 6 & 0.725 \\
\hline Job Satisfaction & 4 & 0.706 \\
\hline
\end{tabular}




\begin{tabular}{|l|l|l|}
\hline Perceived Training effectiveness & 3 & 0.672 \\
\hline Knowledge Transfer & 3 & 0.797 \\
\hline Organizational Commitment & 4 & 0.812 \\
\hline
\end{tabular}

\section{Results and Analysis}

\subsection{Profile of the Respondents}

Personal and demographic information of the respondents is presented in the following table:

\begin{tabular}{|c|c|c|c|}
\hline Variable & Category & Frequency & Percentage \\
\hline Gender & $\begin{array}{l}\text { Male } \\
\text { Female }\end{array}$ & $\begin{array}{l}117 \\
38\end{array}$ & $\begin{array}{l}75 \\
25\end{array}$ \\
\hline Age & $\begin{array}{l}\text { 20-25 years } \\
25-30 \text { years } \\
30-35 \text { years } \\
35-40 \text { years } \\
\text { Above } 40 \text { years }\end{array}$ & $\begin{array}{l}15 \\
44 \\
43 \\
32 \\
21\end{array}$ & $\begin{array}{l}10 \\
28 \\
28 \\
21\end{array}$ \\
\hline Income & $\begin{array}{l}\text { Below } 15000 \\
15000-25000 \\
25000-35000 \\
35000-45000 \\
45000-55000 \\
\text { Above } 55000\end{array}$ & $\begin{array}{l}8 \\
20 \\
28 \\
38 \\
24 \\
37\end{array}$ & $\begin{array}{l}05 \\
13 \\
18 \\
25 \\
15 \\
24\end{array}$ \\
\hline
\end{tabular}




\begin{tabular}{|l|l|l|l|}
\hline Education & Inter & 3 & 2 \\
Bachelor & 29 & 19 \\
Master & 57 & 37 \\
MS/M.Phil. & 50 & 32 \\
& PHD & 16 & 10 \\
\hline
\end{tabular}

\subsection{Hypothesis Testing}

This section of the study finally tests the model after satisfying the requirements of reliability and validity. The casual relationships of the independent variable were measured on dependent variables.

\subsubsection{Employee's Motivation and Intrinsic Reward}

The regression results of the study confirm the significant positive relationship between intrinsic reward and Employee's with $(B e t a=0.115)$ and $(p=0.010)$. According to these results, intrinsic reward contributes more than $11 \%$ to Employee's Motivation. This result of study validates $\mathrm{H} 1$.

\subsubsection{Employee's Motivation and Extrinsic Reward}

According to this result of the study. The variable of extrinsic reward has a significant positive relationship with Employee's Motivation. Specifically, this variable has a significant positive relationship with $(\mathrm{Beta}=0.144)$ and $(\mathrm{p}=0.023)$. That means the intrinsic reward more than $14 \%$ to Employee's Motivation. Results of the current study validate the H2.

\subsubsection{Employee's Motivation and Job Satisfaction}

Regression analysis of the job Satisfaction shows that there is a significant positive relationship with $(B e t a=0.212)$ and $(\mathrm{p}=0.001)$. The results suggest that Job Satisfaction almost more than 21\%to Employee's Motivation. The result of the study support H3.

\subsubsection{Employee's Motivation and Perceived Training Effectiveness}

The regression results of the study confirm the insignificant negative relationship between Perceived Training Effectiveness and Employee's Motivation with (Beta=-0.39) and $(\mathrm{p}=0.208)$. According to these results, PTE is almost $25 \%$ to Employee's Motivation. The result of the study does not support $\mathrm{H} 4$.

4.1.5 Knowledge Transfer and Employee's Motivation The regression result of the study confirm the significant positive relationship between Employee's Motivation and Knowledge Transfer with (beta=0.206) and $(\mathrm{p}=0.012)$. According to these results, Employee's Motivation is more than 20\%to Knowledge transfer. The Result of study support H5. 


\section{Macrothink \\ International Journal of Human Resource Studies \\ ISSN 2162-3058 \\ 2014, Vol. 4, No. 3}

\subsubsection{Organization Commitment an Employees Motivation}

The regression result of the study confirm the significant positive relationshipbetween Employee's Motivation and organizational commitment with (beta=0.509)and $(\mathrm{p}=0.000)$. According to these results, Employee's Motivation is more than 50\%to Organizational Commitment. The result of study support H6.

Table: Regression Results

\begin{tabular}{|c|c|c|c|c|c|c|}
\hline Hypothesis & Model Variables & Estimate & S.E. & C.R. & $\mathbf{P}$ & Results \\
\hline H1 & $\begin{array}{ll}\text { Intrinsic } & \text { Reward } \\
\text { Employee's } & \\
\text { Motivation } & \end{array}$ & 0.115 & 0.117 & 1.018 & .010 & Supported \\
\hline H2 & $\begin{array}{ll}\text { Extrigsic } & \text { Reward } \\
\text { Employee's } & \\
\text { Motivation } & \end{array}$ & 0.144 & 0.101 & 137.1 & .023 & Supported \\
\hline H3 & $\begin{array}{l}\text { Job Satisfaction } \\
\text { Empłैoyee's } \\
\text { Motivation }\end{array}$ & 0.212 & 0.105 & 1.759 & .001 & Supported \\
\hline H4 & $\begin{array}{l}\text { PTE } \longrightarrow \\
\text { Employee's } \\
\quad \text { Motivation }\end{array}$ & -0.390 & .072 & -2.702 & .208 & $\begin{array}{l}\text { Not } \\
\text { Supported }\end{array}$ \\
\hline H5 & $\begin{array}{l}\underset{\substack{\text { Knowledge } \\
\text { Transfer }}}{\text { Employee's Motivation }} \\
\underbrace{2} \text {. }\end{array}$ & 0.206 & 0.098 & 2.551 & $\begin{array}{l}0.01 \\
2\end{array}$ & Supported \\
\hline H6 & $\begin{array}{l}\text { Employee's Motivation } \\
\text { Organizational } \\
\text { Commitment }\end{array}$ & 0.509 & 0.086 & 7.171 & $\begin{array}{l}0.00 \\
0\end{array}$ & Supported \\
\hline
\end{tabular}


Figure: Structural Model Results

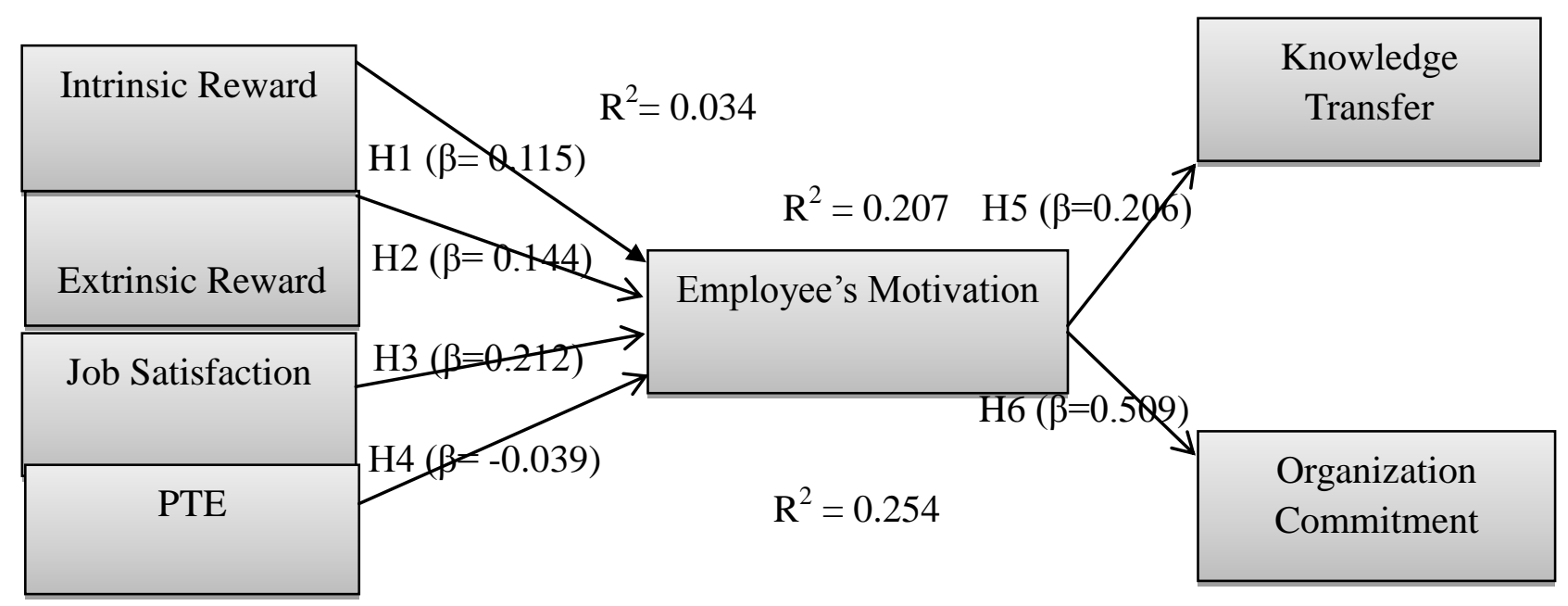

\section{Discussion}

It is concluded from the research that management is capable and can manipulate different useful procedures and campaigns to encourage employees and provoke their stimuli in workplace environments. It is obvious that different tactics, strategies and policies may have unusual motivational effects on different people in different situations. The plans of motivation must have the authenticity to elevate motivation and drive it to one way and devalue and shrink in another way. The tools of motivation should be taken for sure accomplishment. It is extremely necessary to take into account the unique quality of condition and team of different people. As different people in organization belong to different cultures therefore, it is the job of management to consider different alternatives according to situation. The study specifies that employee motivation is the result of several factors. Significant information was achieved that rewards and employee motivation have positive and direct relationship. Simply, change in reward offer will have same effect of change in employee work motivation and with high performance levels. If organization provides good pays, bonuses and promotion to do things effectively then employees will be motivated toward organization goal.

In this study we conclude that intrinsic reward (Working Condition, Recognition, and Authority) has significant positive effect on employee's motivation. If organizations provide good working condition to their employee' to work comfortably, authority to make decision and control things and recognition to their employees for their extra effortsand also for their achievement then they will be generate positive result for the organization and vice versa. Intrinsic reward as well as Extrinsic reward (Promotion. Pay, Bonuses) has also significant positive impact on employee's motivations. It's necessary for betterment of any organization 
it should be provide healthy salary for the efforts of the employee's, Bonuses for their extra effort and promote them according to their performance and according to their work experience in the organization.

Job satisfaction has also play important role in enhancing employee's motivation. If we keenly observe job satisfaction highly related with the Intrinsic and Extrinsic rewards. To some extent job satisfaction is related to perceived training effectiveness. When any organization providing good Intrinsic (Working condition, Recognition, Authority) and extrinsic (Pay, Promotion, Bonuses) Rewards as well as effective training to the employees then employees will be satisfied and highly motivated to achieve organizations goals. If any organization not provides effective training to the employees then they will not perform their duties well, and also not motivated toward their work.

In this case we have collected data from public sector, because learning in public sector through training is not effective. Trainers just tell them about their tasks and duties but there is not practical application on their jobs. That's why we can say that there is no motivation even after getting the training. So we can conclude that the relationship between employee's motivation and PTE is not supported.

These independent variables (Intrinsic reward, Extrinsic reward, job Satisfaction, Perceived training effectiveness) leads to employee's motivation and further employee's motivation lead to knowledge transfer and organizational Commitment. If an employee is motivated then he will tend to share his knowledge his experience with his colleague and as well as with his sub-ordinates. And Employee's motivations also have impact on organizational commitment. If an employee is motivated toward his work then its show his commitment toward his organization in which he is working.

\section{Limitation/ Future Research}

Limitations of the current study should be noted. First of all, it was conducted with the use of a convenience sample in a contrived setting. There is a need to repeat this research with the use of more representative random samples. Since the sample was not random, responses may have been elicited from more cooperative people, and their responses may have been influenced by social attraction. There are certain limitations of the study which can be taken into account for further studies in the future, like sample size was too small and data gather from the public sector of Bahawalpur was considered. Another important limitation was that the pay structure of the organizations was different from one another, so responses regarding extrinsic reward variable were deviating, generating slightly significant impact of pay on employee motivation. These limitations can be avoided in the future studies carried out in this field, and a more clear picture can be obtained regarding impact of extrinsic and intrinsic rewards on employee motivation. Future studies would gain external validity by using probability samples of wider populations. Because this study was cross-sectional, causality cannot be inferred. However, the results of our model provide some preliminary support for the relationship between motivation and different variable. If we conduct this research in public and private sectors then the results will be effective to make decision. 


\section{Ml Macrothink}

\section{References:}

- ] Bishop, J. (1987), "The Recognition and Reward of Employee Performance", Journal of Labor Economics, 5(4), p.2.

- Bishop, J. (1987). The recognition \& Reward of Employee Performance, Journal of Labor Economics Vol. 5, No. 4 Part 2: The New Economics of Personnel pp. S36-S56.

- Luthans, F. (1998). Organizational Behavior. Boston: Irwin McGraw-Hill.

- Luthans, Fred, Harriette S. McCaul, Nancy G. Dodd (1985). Organizational Commitment: A Comparison of American, Japanese, and Korean Employees, The Academy of Management Journal, 28(1), pp.213-219.

- Moser, K. (1997). Commitment in organizations. Psychologies, 41 (4), pp.160-170.

- Rusbult, C. E., Farrell, D., Rogers, D., \& Mainous, A. G. (1988). Impact of exchange variables on exit, voice, loyalty, and neglect: An integrative

- Tai, W.T. (2006), "Effects of training framing general self-efficacy and training motivation ontrainees' training effectiveness", Personnel Review, Vol. 35 No. 1, pp. 51-65.

- Chen, T.Y., Chang, P.L. and Yeh, C.W. (2004), "A study of career needs, career development programs, job satisfaction and the turnover intensity of $R$ \& $D$ personnel", Career Development International, Vol. 9 No. 4, pp. 424-37.

- Huysman, M. and de Wit, D. (2004), "Practices of managing knowledge sharing: towards a second wave of knowledge management", Knowledge and Process Management, Vol. 11 No. 2, pp. 81-92.

- Ryan, R.M. and Deci, E.L. (2000), "Intrinsic and extrinsic motivations: classic definitions and new directions", Contemporary Educational Psychology, Vol. 25 No. 1, pp. 54-67.

- Walsh, J.P. (1995), “Managerial and organizational cognition: notes from a trip down memory lane", Organization Science, Vol. 6 No. 3, pp. 280-321.

- Lin, H. (2007), "Effects of extrinsic and intrinsic motivation on employee knowledge sharing intentions", Journal of Information Science, Vol. 33 No. 2, pp. 135-49.

- Lucas, L.M. and Ogilvie, D. (2006), “Things are not always what they seem. How reputations, culture and incentives in flouncy knowledge transfer", The Learning Organization, Vol. 13 No. 1, pp. 7-24.

- Mowday, R.T., Porter, L.W., \& Steers, R.M. (1982). Employee's organization linkages. New York: Academic Press.

- Porter, L.W.; Steers, R.M.; Mowday, R.T.; \& Boulian, P.V. (1974). Organizational commitment, job satisfaction, and turnover among psychiatric technicians. Journal of 
Applied Psychology, 59, pp.603-609.

- Luthans, Fred, Harriette S. McCaul, Nancy G. Dodd (1985). Organizational Commitment: A Comparison of American, Japanese, and Korean Employees, The Academy of Management Journal, 28(1), pp.213-219.

- Meyer, J. P. \& Allen, N. J. (1991). A three component conceptualization of organizational commitment. Human Resource Management Review, 1(1), pp.61-89.

- Brown, Barbara B. (2003). Employees' Organizational Commitment and Their Perception of Supervisors' Relations-Oriented and Task-OrientedLeadership Behaviors, Virginia Polytechnic Institute and State University, $\mathrm{PhD}$ Thesis. Motivation and Self-regulation across the Life Span, Cambridge University Press, New York, NY, pp.341-64.

- Baron, R. A. (1983). Behavior in organizations, p. 123, New York: Allyn \& Bacon, Inc.

- Frey. B. (1997). On the Relationship between Intrinsic and Extrinsic Work Motivation. International Journal of Industrial Organization, 15, p 427 - 439

- Meyer, J. P. \& Allen, N. J. (1991). A three component conceptualization of organizational commitment. Human Resource Management Review, 1(1), pp.61-89.

- Pool, S. and Pool, B. (2007), “A management development model”, Journal of ManagementDevelopment, Vol. 26 No. 4, pp. 353-69.

- Mowday, R.T., Porter, L.W., \& Steers, R.M. (1982). Employee's organization linkages. New York: Academic Press.

- Baron, R. A. (1983). Behavior in organizations, p. 123, New York: Allyn \& Bacon, Inc.

- Maslow, A.H. (1968). Toward a psychology of being. New York: John Wiley \& Sons

- Herzberg, F.I. (1987). One more time: How do you motivate employees?, Harvard Business Review, Sep/Oct87, 65(5), 109-120

- Lawler, E. E. (2003). Treat people right. San Francisco: Jossey-Bass Inc. McGraw-Hill Irwin. Mumford, M.D. (2000). Managing Creative People: Strategies and Tactics for Innovation, Human Resource Management Review, Vol.10, No.3, pp.313-351.

- Ajila, C and Abiola, A. (2004). Influence of Rewards on Workers Performance in an Organization, Journal of Social Science, 8(1), pp.7-12

- Porter, L.W., \& Lawler, E.E. (1968). Managerial Attitudes and Performance. Homewood, IL: Dorsey Press.

- Kallerberg, A.L. (1977). Work values and job rewards: A theory of job satisfaction. American Social Review, 42, 124-143. http://dx.doi.org/10.2307/2117735 


\section{Macrothink Institute $^{\mathrm{TM}}$}

- Selden, S.C., \& Brewer, G.A. (2000). Work motivation in the senior executive service: Testing the high performance cycle theory. Journal of Public Administration Research and Theory, 3, 531-550. http://dx.doi.org/10.1093/oxfordjournals. jpart.a024280

- Malhotra, N., Budhwar, P., \& Prowse, P. (2007). Linking rewards to commitment: An empirical investigation of four UK call center'sInternational Journal of Human Resource Management, 18(12), 2095-2017. http://dx.doi. org/10.1080/09585190701695267

- Rizwan, M., Shahzad, N., Sheikh, Q., Batool, S., Riaz, M. \& Saddique, S. (2013) Variables that Have an Impact on Employee Satisfaction And Turnover Intention, International Journal of Research in Commerce, Economics and Management, 3(3), $131-138$

- Mottaz, C.J. (1985). The relative importance of intrinsic and extrinsic rewards as determinants of work satisfaction. The Sociological Quarterly, 26(3), 365-385. http://dx.doi.org/10.1111/j.1533-8525.1985.tb00233.x

- Weatherly, R.L. (2002). Effects of external rewards on internal motivation and job satisfaction. Master's thesis. Retrieved n.d., from http://etd.lib.ttu.edu/theses/ available/etd-0731200831295017084509/unrestricted/31295017084509.pdf

- Katz, R., \& Van Maanan, J. (1977). The loci of work satisfaction: Job interaction and policy. Human Relations, 30, 469-486. http://dx.doi.org/10.1177/001872677703000505

- Eisenberger, R., Stinglhamber, F., Vandenberghe, C., Sucharski, I.L., \& Rhoades, L. (2002). Perceived supervisor support: Contributions to perceived organizational support and employee retention. Journal of Applied Psychology, 87(3), 565-573. http://dx.doi.org/10.1037/0021-9010.87.3.565, PMid:12090614

- Younas, M., Rizwan, M., Khan, S., Majeed, Z., Khalid, S. \& Anjum, S. (2013) The Impact of Some Specific Factors on Employee Satisfaction: An Empirical Study from Pakistan. Journal of Basic and Applied Scientific Research, 3(12), 323-334

- Randall, D.M., \& O’Driscoll, M.P. (1997). Affective versus calculative commitment: Human resource implications. The Journal of Social Psychology, 137(5), 606-617. http://dx.doi.org/10.1080/00224549709595482

- Williams, M.L., Brower, H.H., Ford, L.R., Williams, L.J., \& Carraher, S. (2008). A comprehensive model and measure of compensation satisfaction. Journal of Occupational and Organizational Psychology, 81, 639-668. http://dx.doi. org/10.1348/096317907X248851

- Amabile, T.M., Schatzel, E.A., Moneta, G.B., \& Kramer, S.J. (2004). Leader behaviors and the work environment for creativity: Perceived leader support. The Leadership Quarterly, 15, 5-32. http://dx.doi.org/10.1016/j.leaqua.2003.12.003 